\title{
Empowerment Influence on Turnover Intention of Public Secondary School Teachers in Katsina State Nigeria
}

\author{
Salisu Abba Yangaiya iD \\ Department of Educational Foundations Federal University PMB: 5001 Dutsinma, Katsina State Nigeria
}

sayangaiya@fudutsinma.edu.ng

\section{ARTICLE INFORMATION}

Received: August 31, 2020

Revised: November 23, 2020

Accepted: December 10, 2020

Published Online: March 31, 2021

\section{Keywords:}

Turnover intention, Empowerment, Secondary school, Teachers, Regression analysis, Nigeria

\section{ABSTRACT}

Background: Secondary school teacher's turnover is one of the problems bedeviling education sector in Katsina state. The sector can hardly be improved unless the situation is changed. To change the situation the stakeholders should focus on the need to enhance secondary school teacher's satisfaction, commitment and empowerment.

Purpose: The study examines the influence of empowerment on turnover intention of teachers of public secondary schools in Katsina State Nigeria. In addition the study examines which dimension among the dimensions of empowerment best influences turnover intention of teachers of public secondary schools in Katsina state, Nigeria.

Methods: Empowerment and Turnover Intention questionnaires were used to get the needed data. Multiple regression analysis was used to analyze the data gathered using SPSS version 20.0.

Results: The results show that the dimensions of empowerment significantly and negatively explain $40 \%$ of variance of turnover intention. Additionally, among the dimensions of empowerment namely; perceived control, perceived competence and goal internalization, perceived competence makes the largest contribution followed by perceived control; beta -.35 and -.31 respectively.

Conclusion: the study establishes that empowerment significantly and negatively relates to turnover intention of teachers of public secondary schools in Katsina state Nigeria.

\section{Introduction}

In Nigeria secondary education is regarded as education students acquire after successful completion of primary education. It comprises of junior secondary and senior secondary school of three years duration each. Secondary education in Nigeria was designed to prepare the beneficiaries for meaningful leaving as well as opportunity for education of higher quality irrespective of their background (Federal Republic of Nigeria, 2004).

However, secondary education in Nigeria is bedeviled with a lot of challenges. These challenges include; overcrowded classrooms, lack of enough facilities, poor remuneration, teacher burnout, teacher turnover among others (Federal Republic of Nigeria, 2004). Of all the challenges highlighted above, turnover seems to be the most difficult to address. This is because of the cost involved in hiring a replacement to those that left the organization, training of the newly employed staff among others (Arshad \& Puteh, 2015). To address some of these challenges especially turnover the few teachers available need to be motivated and empowered. This study therefore, intends to examine how empowerment relates to turnover intention of teachers of public secondary schools in Katsina state, Nigeria. The study come up with following research questions.

1. Does empowerment relates with turnover intention of teachers of public secondary in Katsina state, Nigeria?

2. How well do the three dimensions of empowerment explain turnover intention of teachers of public secondary school in Katsina state, Nigeria?

\section{Literature Review}

\subsection{Turnover Intention}

Turnover intention can be defined as individual's intention to voluntarily quit the organization or 
profession (Jha, 2009; Thiranagama, 2015). Similarly, (Belete, 2018) views turnover intention as a likelihood of a staff to leave the current job he is doing either voluntarily or involuntarily. In addition, turnover intention is regarded as pre-requisite of an employee to finally leave his job or organization (Belete, 2018). Stress and dissatisfaction have been identified as some of the reasons that trigger employees' turnover intention (Arshad \& Puteh, 2015).

\subsection{Empowerment and Turnover Intention}

Empowerment can be regarded as giving opportunities to the subordinates to air their views on issues that directly affect the smooth running of the organization in order to shape the goals of the organization and positively affect organizational outcomes (Renihan \& Renihan, 1992; Menon, 2001). Additionally, (Ripley \& Ripley, 1992) argue that empowerment has to do with giving members of the organization the leverage to approve and decide on issues that affect the organization, where such power is the prerogative of those at the helm of affairs. According to (Dee, Henkin \& Duemer, 2002) empowerment can be viewed as impressions the subordinates have towards their organization not necessarily what the superordinate does to them.

It is worth noting that giving employees power or leverage to air their views in decision making that affect the organization does not in any way means relinquishing power of the organization by the super ordinate to the empowered subordinate. Moreover, as stress by (Ripley \& Ripley, 1992), it only alters and transforms the way that power is being practice in the organization. Empowerment is a multidimensional construct (Short \& Rinehart, 1992; Sprietzer, 1995; Menon, 2001). According to (Menon, 2001), empowerment consists of three dimensions. These dimensions are; perceived control, perceived competence and goal internalization. Perceived control is regarded as beliefs about freedom in planning and execution of work, as well as relative freedom in authority and decision making. Perceived competence means feeling by individual that he can effectively discharges his scheduled responsibility and any other work that may crop up. Last but not the least, Goal internalization means cherishing and believing in the goals of the organization by the subordinate and his desire and readiness to see to its realization (Menon, 2001).

In their study (Ali, Huang, Ali \& Li, 2017) found that empowerment relates negatively and significantly with turnover intention. In addition, (Yang \& Lee, 2009) in their study titled linking empowerment and job enrichment with turnover intention: The influence of job satisfaction reveal that empowerment significantly but indirectly relates to turnover intentions with job satisfaction as mediating variable. Similarly (Anil, 2019) in his study on employee empowerment and turnover intention found that empowerment relates negatively with turnover intention. In their meta-analysis study on antecedents of turnover intention in USA (Ozkan, Elci, Karabay, Kitapci \& Garip, 2020) found that empowerment relates negatively and significantly with turnover intention. Base on the above theoretical arguments the following hypotheses were developed:

H1. There is significant negative relationship between empowerment and turnover intention among secondary school teachers in Katsina state, Nigeria. $\mathrm{H} 2$. All the three dimensions of empowerment predict significantly and negatively Turnover Intentions of secondary school teachers in Katsina state, Nigeria.

\section{Method of Data Collection and Analysis}

\subsection{Instruments Used in the Study}

Two questionnaires were used in this study. These are: Empowerment Questionnaire (EQ) and Turnover Intention Questionnaire (TIQ). Both questionnaires were duly adapted by the researcher and were adopted from (Menon, 2001) and (Seashore, Lawler, Marvis \& Cammmann, 1992) respectively. According to (Menon, 2001) empowerment has three dimensions, with three items each. The dimensions are; perceived control, perceived competence and goal internalization. Some of the items read thus, I have the authority to make decisions at work, I have the competence to do my work effectively, and I am enthusiastic about working towards the organization objective, for perceived control, perceived competence and goal internalization respectively. However, TI as argue by (Seashore, Lawler, Marvis \& Cammmann, 1992) is uni-dimensional and has four items. Sample of the items was; you are very likely to 
stay in this institution for the next five years. All the questionnaires were rated using Likert's seven-point scale. The rating varies between Strongly Disagree (SD), equivalent to 1 point, to strongly agree (SA) with 7 points.

\subsection{Sample}

Four hundred questionnaires were distributed physically to teachers of public secondary schools in Katsina state, in order to collect the data required for the study. Three hundred and sixty four questionnaires were returned, while three hundred and fifty were used in the study. Fourteen questionnaires were excluded in the study because of some missing informations (Pallant, 2007). Of the three hundred and fifty respondents two hundred and eighty were male and seventy females representing $80 \%$ and $20 \%$, respectively. Regarding the age of the respondents one hundred and thirty are between 20-30 years, one hundred and twenty between 3140 years and one hundred respondents are above 40 years representing $37 \%, 34 \%$ and $29 \%$, respectively. Similarly, one hundred respondents have $1-5$ years' experience as teachers. Additionally, one hundred and seventy five respondents have 6-10 years teaching experience while, seventy five respondents have more than 11 years teaching experience equivalent to $29 \%, 50 \%$ and $21 \%$ respectively.

\subsection{Data Analysis}

Descriptive statistics and multiple regression were used for data analysis. Demographic data of the respondents was analyzed using descriptive statistics, while multiple regression was used to examine how independent variables and dependent variable relate. SPSS program was used for data analysis.

\section{Results of the Study}

Table 1, highlights the correlations of the dimensions of empowerment (independent variable) and turnover intention (dependent variable). The dimensions of empowerment correlate substantially with turnover intention. The correlation ranges between -.424 to -.566 . In addition, the correlation between the dimensions of empowerment is reasonable and within the acceptable limit of $<.7$ (Pallant, 2007).
Table 1: Correlations of the Variables of Study.

\begin{tabular}{|l|l|l|l|}
\hline Variable (s) & $\begin{array}{l}\text { Perceived } \\
\text { control }\end{array}$ & $\begin{array}{l}\text { Perceived } \\
\text { competence }\end{array}$ & $\begin{array}{l}\text { Goal } \\
\text { internalization }\end{array}$ \\
\hline Total TI & -540 & -566 & -424 \\
\hline Perceived Control & & 540 & 473 \\
\hline $\begin{array}{l}\text { Perceived } \\
\text { Competence }\end{array}$ & & 537 \\
\hline $\begin{array}{l}\text { Goal } \\
\text { Internalization. }\end{array}$ & & & \\
\hline
\end{tabular}

Correlations of Variables of study $\mathrm{p}<.0001$

To assess how three dimensions of empowerment (independent variable) predict Turnover Intention (Dependent Variable) multiple regression analysis was used. Result depicts that all the three dimensions of independent variable are predictors of dependent variable. Forty percent of the variance of Turnover Intention (TI) was explained by the dimensions (F. 44.25) $=3,197 \mathrm{p}$.001. Thus, hypothesis one (H1) which states that there is significant negative relationship between empowerment and turnover intention among secondary school teachers in Katsina state is accepted.

Furthermore, the result reveals that among the dimensions of empowerment Perceived competence makes the largest unique contribution (beta $=-.35$ ), followed by perceived control (beta $=-.31$ ). But it is worth noting that goal internalization though explains TI (beta $=-.09$ ), the relationship is not statistically significant $(\mathrm{p}>.05)$. Thus, hypothesis two (H2) which says that all the three dimensions of empowerment significantly and negatively predicts TI among secondary teachers in Katsina state is rejected, as only two dimensions significantly predicts TI.

Table 2: F test value and Regression Coefficients for TI.

\begin{tabular}{|l|l|l|l|l|l|l|}
\hline Variable(s) & $\mathbf{B}$ & SE & Beta & Sign. & $\mathbf{F}$ & $\mathbf{R}^{\mathbf{2}}$ \\
\hline $\begin{array}{l}\text { Turnover } \\
\text { Intention }\end{array}$ & 28.610 & 1.862 & & .000 & $\begin{array}{l}44.25 \\
(3,197)\end{array}$ & .40 \\
\hline $\begin{array}{l}\text { Perceived } \\
\text { Control }\end{array}$ & -1.194 & 263 & -307 & .000 & & \\
\hline $\begin{array}{l}\text { Perceived } \\
\text { Competence }\end{array}$ & -1.448 & 291 & -352 & .000 & & \\
\hline $\begin{array}{l}\text { Goal } \\
\text { Internalization }\end{array}$ & -451 & 341 & -090 & .187 & & \\
\hline
\end{tabular}




\section{Discussion}

This study examines how teachers' empowerment relates with turnover intention in public secondary schools in Katsina state Nigeria. The following research hypotheses were postulated to guide the study:

H1 Teachers' empowerment relates significantly and negatively with turnover intentions in public secondary school in Katsina state

H2. Dimensions of empowerment significantly and negatively predict Turnover Intentions of teachers of public secondary schools in Katsina state.

Correlation of the variables used in the study were highlighted in Table 1 . The dimensions of empowerment; perceived control, perceived competence and goal internalization correlate substantially with turnover intention $(-.540,-.566$ and -.424$)$ respectively. Moreover the correlation between the dimensions of empowerment is reasonable, acceptable and within the threshold point of $<.7$ (Pallant, 2007).

Additionally, the results show that the dimensions of independent variable predict dependent variable (R-Square .40). This result supports hypothesis one (H1) which says that Teachers' empowerment relates significantly and negatively with turnover intentions in public secondary school in Katsina state. Additionally, perceived competence and perceived control predict turnover intention better (beta $=-.35$ and -.31 , p .000) respectively. However, goal internalization through predicts TI (beta $=-.09$ ) but, the relationship is not statistically significant $(\mathrm{p}>.05)$. Thus, hypothesis two which states that; Dimensions of empowerment significantly and negatively predict Turnover Intentions of teachers of public secondary schools in Katsina state is rejected. The results concur with similar studies (Yang \& Lee, 2009; Ali, Huang, Ali \& Li, 2017; Anil, 2019) who found that empowerment relates significantly and negatively with turnover intention.

The study has both practical and theoretical implication. It shows that turnover intention can be minimized if teachers are empowered. Principals, vice principals and other stakeholders can enhance teachers empowerment by given them relative autonomy in their day to day activities as well as involving them in decision making that directly affect their work. Furthermore, the results will be useful to the scholars, as little or no research was earlier conducted to examine how teacher's empowerment relates with with turnover intention among teachers of public secondary schools in Nigeria in general and Katsina state in particular.

\section{Limitations}

The results of this study could not be generalized to all secondary schools in Katsina state, Nigeria, because only public secondary schools were used. Similar study should be conducted to private secondary schools in the state before generalization.

\section{Conclusion}

The study examines how empowerment relates to turnover intention of teachers of public secondary school in Katsina state, Nigeria. Additionally, it assesses the contribution of each of the empowerment dimensions to the prediction of turnover intention. The study establishes that empowerment significantly and negatively relates to turnover intention (R-Square .40). However, only two out of three dimensions of empowerment significantly and negatively predicts turnover intention as shown in Table 2. Consequently, the study accepts hypothesis one and rejects hypothesis two accordingly.

\section{References}

Ali, A, Huang, J., Ali, Z \& Li, Z. (2017). Impact of Empowerment on Employee Turnover Intention: The Influence of Job Satisfaction. Proceedings of the 2017 2nd International Conference on Education, Management Science and Economics (ICEMSE 2017), 42-46. https://doi.org/10.2991/icemse-17.2017.10

Ali, N. (2013). Effects of Employees' Empowerment on Employees' Commitment to Organization and Employees' Turnover Intention (An Empirical Evidence from Banking Industry of KPK, Pakistan). $3^{\text {rd }}$ International Conference on Management, Economics and Social Sciences (ICMESS'2013), Kuala Lumpur (Malaysia). Retrieved from http://psrcentre.org/images/ extraimages/phpm7.pdf

Anil, S. (2019). Employee Empowerment and Turnover Intention. International Journal of Management, IT and Engineering, 9(1), 292-303.

Arshad, H., \& Puteh, F. (2015). Determinants of Turnover Intention among Employees. Journal of Administrative Science, 12(2), 1-15. 
Belete, A.K. (2018). Turnover Intention Influencing factors of Employees: An Empirical Work Review. Journal of Entrepreneurship \& Organization Management, 7(3), 1000253. https://doi.org/10.4172/2169-026X.1000253

Dee, J.R., Henkin, A.B., \& Duemer, I. (2002). Structural Antecedents and Psychological Correlates of Teacher Empowerment. Journal of Educational Administration, 41(3), 257-277. https://doi.org/10.1108/09578230310474412

Federal Republic of Nigeria (2004). National Policy on Education, Abuja. Nigerian Educational Research and Development Council.

Jha, S. (2009). Determinants of Employee Turnover Intentions: A Review. Management Today, 9(2), 26- 33.

Menon, S.T. (2001). Employee Empowerment: An Integrative Psychological Approach. Applied Psychology: An International Review, 50(1), 153-180. https://doi.org/10.1111/1464-0597.00052

Ozkan, A.H., Elci, M., Karabay, M.E., Kitapci, H., \& Garip, C. (2020). Antecedents of Turnover Intentions: A Meta-analysis study in the United States. $E$ \& $M$ Economics and Management, 23(1), 93-110. https://doi.org/10.15240/tul/001/2020-1-007

Pallant, J. (2007). Survival Manual: A step by Step Guide to Data Analysis Using SPSS for Windows. New York, Open University Press.

Renihan, F.I., \& Renihan, P.J. (1992). Educational Leadership: A Renaissance Metaphor. Education Canada, 32(1), 8-14.
Ripley, R.E., \& Ripley, M.J. (1992). Empowerment the corner stone of Quality: Empower-ing Management in Innovative Organization in the 1990's. Management Decision, 30(4), 20-43. https://doi.org/10.1108/00251749210014743

Seashore, S.E., Lawler, E.E., Marvis, P.H., \& Cammmann, C. (1992). Observing and Measuring Organizational Change: A Guide to Field Practice, New York, Wilary.

Short, P.M., \& Rinehart, J.S. (1992). School Participant Empowerment Scale: Assessment of Level of Empowerment within the School Environment. Educational and Psychological Measurement, 52(4), 951-960. https://doi.org/10.1177/0013164492052004018

Sprietzer, G.M. (1995). Psychological Empowerment in the Work Place, Dimensions, Measurement and Validation. Academy of Management Journal, 38(5), 1442-1465.

Thiranagama, A.W. (2015). Organizational Commitment and Turnover Intention (A Quan-titative Analysis of Sri- Lanka Apparel Firm). International Journal of Science and Research, 6(2), 412-419.

Yang, S.-B., \& Lee, K.-H. (2009). Linking Empowerment and Job Enrichment to Turnover Intention: The Influence of Job Satisfaction. International Review of Public Administration, 14(2), 13-24. https://doi.org/10.1080/12294659.2009.10805152 


\section{Issues and Ideas in Education}

Chitkara University, Saraswati Kendra, SCO 160-161, Sector 9-C, Chandigarh, 160009, India

\section{CHITKARA}

Volume 9, Issue 1

March 2021

ISSN 2320-7655

Copyright: [C 2021 Salisu Abba Yangaiya] This is an Open Access article published in Issues and Ideas in Education (Issues Ideas Educ.) by Chitkara University Publications. It is published with a Creative Commons Attribution- CC-BY 4.0 International License. This license permits unrestricted use, distribution, and reproduction in any medium, provided the original author and source are credited. 